\title{
HỒI SỨC PHÌNH BÓC TÁCH ĐỘNG MẠCH CHỦ NGỰC STANFORD A Ở BỆNH NHÂN NŨ CÓ THAI: NHÂN 3 TRƯỜNG HỢP LÂM SÀNG
}

\section{TÓM TÁT}

3 BN đều nhập viện cấp cứu vì đau ngực trái, tiền sử không ghi nhận bệnh động mạch chủ (ĐMC), không tăng huyết áp. 1 BN 20 tuổi thai 12 tuần bị bóc tách ĐMC ngực đoạn quai đường kính $60 \mathrm{~mm}$, tụ máu quanh túi phình, khả năng vỡ. $1 \mathrm{BN} 26$ tuổi thai 31 tuần bị phình ĐMC ngực lên, có dấu bóc tách từ đoạn lên kéo dài dến chỗ chia động mạch thận 2 bên, đường kính xoang 62 $\mathrm{mm}$, đoạn lên: $36 \mathrm{~mm}$, hở van ĐMC trung bình. 1 BN 31 tuổi thai 33 tuần bị phình bóc tách gốc ĐMC và dãn nhẹ ĐMC ngực đoạn lên, hở van ĐMC nhẹ. $2 \mathrm{BN}$ thai 31 tuần và 33 tuần được tiến hành phẫu thuật lấy thai trước và phẫu thuật điều trị PBTĐMCN sau, 2 bé sơ sinh được chăm sóc tốt tại bệnh viện phụ sản. Cả 3 thai phụ được điều trị phẫu thuật thay phình ĐMC ngực đoạn lên, 1 thai phụ thay van ĐMC sinh học. Phẫu thuật thành công không biến chứng. Riêng $\mathrm{BN}$ thai 12 tuần được hổ trợ progesterone sau mổ và tiếp tục thai kỳ. PBTĐMCN týp A hiếm gặp trong thai kỳ và gây tử vong rất cao cho cả mẹ và con. Hiện vẫn chưa có nhiều kinh nghiệm và khuyến cáo điều trị. Cần có sự phối hợp điều trị khẩn trương, kịp thời giữa các chuyên khoa sản, phẫu thuật tim và các bác sĩ gây mê, hồi sức.

\section{SUMMARY}

3 patients admitted to hospital with left chest pain, no known risk factors and a negative family history of aortic dissection or connective tissue disease. A 20 -year-old woman, in the 12th week of pregnancy, had spiral computed tomography (CT) with IV contrast revealed aortic arch dissected with a diameter of $60 \mathrm{~mm}$, the hematomas were around the aneurysm. A 26year-old woman, in the 31th week of pregnancy, had CT with IV contrast revealed dissection of the aorta from the ascending aorta to the level of

\section{Nguyễn Vĩnh Trinh *, Trần Quyết Tiến *}

renal artery, the diameter size of sinuses of Valsalva is $62 \mathrm{~mm}$, moderate aortic regurgitation by echocardiography. A 31-year-old woman, in the 33th week of pregnancy with aortic root dissection confirmed and mild dilation of the ascending thoracic aorta by $\mathrm{CT}$, mild aortic regurgitation by echocardiography. 2 Women in the 31th and 33th weeks of pregnancy underwent an emergency combined operation, consisting of Cesarean section followed by aortic repair for aortic dissection and 2 newborns was taken to the Neonatal Care Unit for observation. One patient in the $12^{\text {th }}$ week of pregnancy continued her pregnancy after an aortic operation. Aortic dissection is a rare complication of pregnancy with significant morbidity and mortality for both the mother and infant. Clinical experience and treatment with this entity is limited to case reports or small cohorts containing fewer than 20 patients. A good professional relationship between the cardiac surgeons, obstetrics and anesthesiologists is very important for the highquality patient outcome.

\section{I. ĐặT VẤN ĐỀ}

PBTĐMCN týp A là bệnh lý hiếm gặp trong thai kỳ, chiếm 0,4 ca/100.000 BN năm [7], nhưng gây tử vong cao cho mẹ và thai nhi. Tî lệ tử vong tăng $1-3 \%$ mỗi giờ sau nhập viện, chiếm $25 \%$ trong 24 giờ đầu, $70 \%$ trong 1 tuần và $80 \%$ trong 2 tuần [6]. Các yếu tố nguy cơ thường gặp của PBTĐMCN gồm tăng huyết áp (THA), các bệnh lý rối loạn collagen gồm có hội chứng Marfan, hội chứng Ehlers-Danlos, van động mạch chủ

\footnotetext{
* Bệnh viện Chơ Rẫy

Người chịu trách nhiệm khoa học: PGS.TS. Trần Quyết Tiến Ngày nhận bài: 01/05/2018 - Ngày Cho Phép Đăng: 20/05/2018 Phản Biện Khoa học: PGS.TS. Đặng Ngọc Hùng GS.TS. Lê Ngọ Thành
} 
(ĐMC) 2 lá, tiền căn gia đình, chấn thương [2], [8]. Ngoài ra, nồng độ ngày càng cao của estrogen và progesterone trong giai đoạn gần cuối thai kỳ cũng là yếu tố làm thoái hóa thành ĐMC, tương tự như hoại tử lớp áo giữa dạng nang ở những $\mathrm{BN}$ bị bóc tách ĐMC và không mang thai. Những thay đổi cấu trúc thành mạch bao gồm sự tăng sản cơ trơn, giảm axit mucopolysaccharide và sự mất đi tính toàn vẹn của các sợi chun giãn [4]. Từ năm 1984 đến nay, $\mathrm{y}$ văn thế giới ghi nhận 180 ca, do đó các kinh nghiệm lâm sàng và điều trị còn rất hạn chế.

\section{PHƯƠNG PHÁP NGHIÊN CÚU}

Mô tả hàng loạt ca. Các dữ liệu được thu thập trong thời gian 3 năm từ tháng 01-2015 đến tháng 01-2018 tại khoa Hồi sức - Phẫu thuật tim Bệnh viện Chợ Rẫy. Tất cả $3 \mathrm{BN}$ đều được phẫu thuật điều trị thành công PBTĐMCN, trong đó 2 thai phụ được thực hiện mổ bắt con trước, theo sau là phẫu thuật điều trị PBTĐMCN và $1 \mathrm{BN}$ thai 12 tuần được điều trị phẫu thuật thay đoạn cuối ĐMC ngực đoạn lên, quai và đoạn đầu ĐMC xuống bằng prothese, hỗ trợ dưỡng thai sau mỗ trong quá trình nằm viện. Các thông tin của $\mathrm{BN}$ đều được ghi nhận qua các dữ liệu chi tiết từ bệnh án.

\section{KẾT QUẢ}

\section{- Ca lâm sàng thứ 1}

BN nữ Nguyễn Thị Ngọc T. 26 tuổi, PARA 0000, nhập viện ngày 05/06/2015 vì đau ngực trái ngày thứ 1 . Tình trạng lúc nhập viện: $\mathrm{BN}$ tỉnh đau ngực, mạch 90 nhịp/phút, huyết áp (HA) 120/70 $\mathrm{mmHg}$.

Siêu âm tim: Phình ĐMC ngực đoạn lên có dấu bóc tách từ đoạn lên kéo dài đến đoạn xuống, đường kính (ĐK) $48 \mathrm{~mm}$, đoạn ngang: $23 \mathrm{~mm}$, đoạn xuống 22 mm. Hở van ĐMC 2/4, EF: 70\%.

Siêu âm bụng tổng quát: thai sống trong lòng tử cung 31 tuần, tim thai 167 nhịp/phút, đường kính lưỡng đỉnh (Biparietal Diameter BPD): $80 \mathrm{~mm}$.
CT-scan ngực có cản quang: Phình xoang ĐMC, bóc tách ĐMC ngực từ đoạn lên đến chỗ chia ĐM thận 2 bên. ĐK xoang $62 \mathrm{~mm}$, ĐK đoạn lên $36 \mathrm{~mm}$, đoạn quai $28 \mathrm{~mm}$, đoạn xuống $25 \mathrm{~mm}$.

Điều trị: hội chẩn liên viện giữa khoa phẫu thuật tim và $B V$ phụ sản Hùng Vương quyết định mổ lấy thai trước và phẫu thuật điều trị PBTÐMCN ngay sau đó trong cùng một thì. Sử dụng thuốc kích thích sự trưởng thành phổi thai nhi (Betamethasone $5,2 \mathrm{mg} 3$ ống tiêm bắp mỗi 12 giờ). $\mathrm{BN}$ được mổ lấy thai và thắt $2 \mathrm{ĐM}$ tử cung vào thời điểm 20 giờ sau khi nhập viện (thời gian: 60 phút), ngay sau đó được phẫu thuật thay van ĐMC sinh học số 25, Thay ĐMC ngực lên bằng Prothese số 28 , cắm lại 2 lỗ vành (thời gian: 8 giờ).

Hậu phẫu: Không chảy máu và sản dịch ít. $\mathrm{BN}$ tỉnh, sinh hiệu ổn, được ngưng thở máy và rút nội khí quản vào giờ 23 hậu phẫu. Các thuốc điều trị: kháng sinh imipenem và vancomycin, hạ áp bằng nicardipine truyền tĩnh mạch, giảm đau morphine. Xuất viện vào ngày hậu phẫu 17. Bé sơ sinh được chăm sóc tốt tại BV Hùng Vương.

\section{- Ca lâm sàng thứ 2}

BN nữ Nguyễn Quý Thùy D. 31 tuổi, PARA 1001 , nhập viện ngày 21/01/2016 vì đau ngực trái ngày thứ 2 . Tình trạng lúc nhập viện: $\mathrm{BN}$ tỉnh đau ngực, mạch 70 nhịp/phút, HA 130/80 mmHg.

Siêu âm tim: Phình gốc ĐMC (Đk vòng van $23 \mathrm{~mm}$, Valsalva $53 \mathrm{~mm}$, chỗ nối xoang ống 36 $\mathrm{mm}$ ) và có dấu bóc tách, dãn nhẹ ĐMC ngực đoạn lên đk $37 \mathrm{~mm}$, đoạn quai $25 \mathrm{~mm}$, đoạn eo 18 mm. Hở van ĐMC 1,5/4, EF: 769\%. Không tràn dịch màng tim.

Siêu âm bụng tổng quát: thai sống trong lòng tử cung 33 tuần, tim thai 165 nhịp/phút.

CT-scan ngực có cản quang: Phình gốc ĐMC (Đk vòng van $23 \mathrm{~mm}$, Valsalva $53 \mathrm{~mm}$, chỗ nối xoang ống $36 \mathrm{~mm}$ ) và có dấu bóc tách, dãn nhẹ ĐMC ngực đoạn lên đk $37 \mathrm{~mm}$, đoạn qua $25 \mathrm{~mm}$, đoạn eo $18 \mathrm{~mm}$. 
Điều trị: hội chẩn liên viện giữa khoa phẫu thuật tim và $\mathrm{BV}$ phụ sản Hùng Vương quyết định mổ lấy thai trước và phẫu thuật điều trị PBTĐMCN ngay sau đó trong cùng một thì. Sử dụng thuốc kích thích sự trưởng thành phổi thai nhi (Betamethasone $5,2 \mathrm{mg} 3$ ống tiêm bắp mỗi 12 giờ). $\mathrm{BN}$ được mổ lấy thai vào thời điểm 34 giờ sau khi nhập viện (thời gian: 90 phút), bé trái 2600 gam, APGAR 7/8. Ngay sau đó được phẫu thuật sửa van $Đ \mathrm{MC}$, thay $\mathrm{ĐMC}$ ngực lên bằng Prothese valsalva số 28 , cắm lại 2 lỗ vành (thời gian: 7 giờ 45 phút).

Hậu phẫu: Không chảy máu và sản dịch ít. $\mathrm{BN}$ tỉnh, sinh hiệu ổn, được ngưng thở máy và rút nội khí quản vào giờ 26 hậu phẫu. Các thuốc điều trị: kháng sinh Imipenem và Vancomycin, hạ áp bằng Nicardipine truyền tĩnh mạch, giảm đau

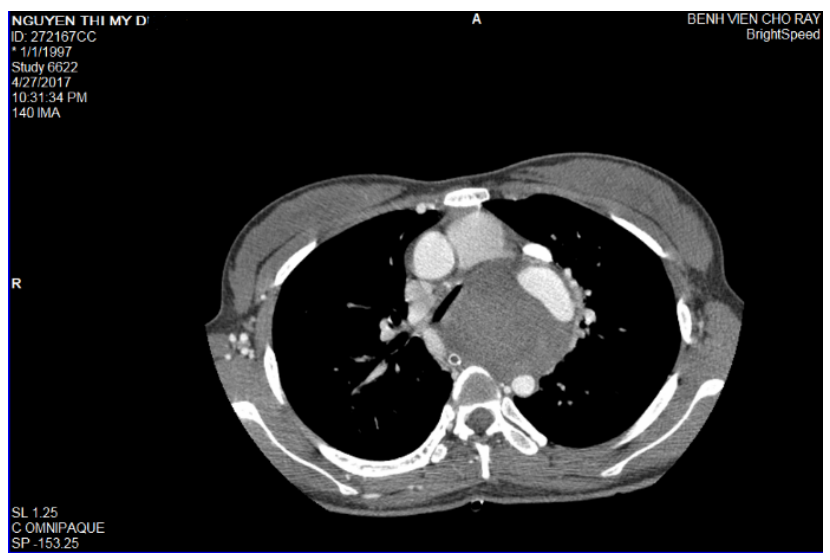

Morphine. Xuất viện vào ngày hậu phẫu 13. Bé sơ sinh được chăm sóc tốt tại BV Hùng Vương.

\section{- Ca lâm sàng thứ 3}

BN nữ Nguyễn Thị Mỹ D. 20 tuổi, PARA 0000, nhập viện ngày 28/04/2017 vì đau ngực trái ngày thứ 7 . Tình trạng lúc nhập viện: $\mathrm{BN}$ lơ mơ, thở máy, mạch 80 nhịp/phút, HA 140/90 mmHg.

Siêu âm tim: Các van tim không hẹp hở, EF: $63 \%$. Không tràn dịch màng tim.

Siêu âm bụng tổng quát: thai sống trong lòng tử cung 12 tuần, tim thai 178 nhịp/phút.

CT-scan ngực có cản quang: Phình ĐMC ngực lên có dấu bóc tách từ đoạn lên kéo dài dến chỗ chia ĐM thận 2 bên, ĐK xoang $62 \mathrm{~mm}$, đoạn lên: $36 \mathrm{~mm}$, quai $28 \mathrm{~mm}$, xuống $25 \mathrm{~mm}$ (Hình 1).

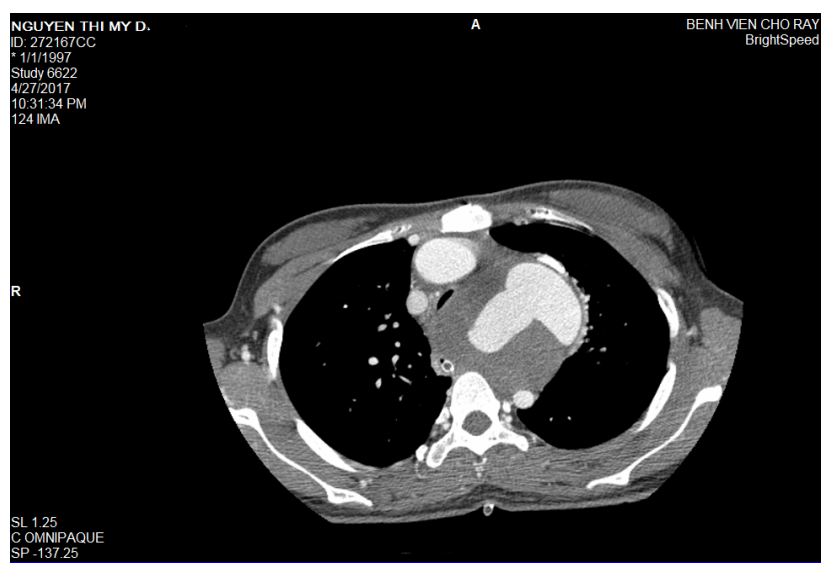

Hinh. 1. Phình bóc tách ĐMC ngục đoạn lên.

Điều trị: $\mathrm{BN}$ được chuyển vào phòng hồi sức khoa Phẫu thuật tim, tiếp tục thở máy, thuốc an thần, hạ áp với Nicardipine truyền tĩnh mạch. Hội chẩn liên viện giữa khoa phẫu thuật tim và $\mathrm{BV}$ phụ sản Hùng Vương quyết định phẫu thuật điều trị PBTĐMCN cấp cứu và hổ trợ dưỡng thai sau mổ. Nếu thai sảy trong quá trình mổ gây băng huyết sau sanh, bác sĩ sản khoa sẽ hỗ trợ cầm máu tử cung ngay trong mổ. Phẫu thuật: thay đoạn cuối ĐMC ngực đoạn lên, đoạn quai và đoạn đầu ĐMC xuống bằng prothese số 25 , cắm lại ĐM thân cánh tay đầu phải, ĐM cảnh chung trái vào prothese, nối $\mathrm{ĐM}$ dưới đòn trái vào prothese bằng prothese số 10 (thời gian: 7 giờ 10 phút).
Hậu phẫu: Không chảy máu. BN tỉnh, sinh hiệu ổn, được ngưng thở máy và rút nội khí quản vào giờ 30 hậu phẫu. Các thuốc điều trị: kháng sinh Imipenem và Vancomycin, hạ áp bằng Nicardipine truyền tĩnh mạch, giảm đau morphine, Cyclogest (progesterone) 0,4 g 1 viên nhét hậu môn mỗi 12 giờ. Xuất viện vào ngày hậu phẫu 19.

\section{BÀN LUẬN}

PBTĐMCN hiếm khi xảy ra ở người nữ trẻ tuổi, thống kê cho thấy có $50 \%$ các ca bóc tách ĐMC gặp ở những người nữ < 40 tuổi đang trong quá trình mang thai với tỉ lệ mắc phải cao nhất là vào tam cá nguyệt thứ $3(50 \%)$ [1] và đây cũng là 
giai đoạn có sự tác động gây căng thành ĐMC cao nhất trong thời kỳ mang thai do sự tăng lên tối đa của nhịp tim, thể tích nhát bóp của tim, cung lượng tim, khối cơ thành thất trái và đường kính cuối tâm trương thất trái. Ngoài ra, trong thai kỳ, estrogen còn là yếu tố làm ức chế sự tích tụ của collagen và các sợi chun ở thành ĐMC, còn progesteron lại là yếu tố làm tăng tốc sự tích tụ các protein không phải collagen trong thành ĐMC. Chính các yếu tố vừa nêu tạo nên sự phân mảnh các sợi lưới, làm giảm lượng mucopolysaccharide và thúc đẩy thêm nữa sự mất đi tính chun lại của các sợi chun giãn thành ĐMC [4]. Hầu hết các trường hợp PBTĐMCN týp A trong thai kỳ đều có liên hệ đến các bệnh mô liên kết (hội chứng Marfan, hội chứng Ehlers-Danlos) cũng như có các yếu tố nguy cơ khác như THA, bệnh tim bẩm sinh (van ĐMC 2 lá). $3 \mathrm{BN}$ vừa trình bày ở trên đều $<40$ tuổi, trong đó $2 \mathrm{BN}$ bị PBTĐMCN týp $A$ vào tam cá nguyệt thứ 3 . Tuy nhiên cả $3 \mathrm{BN}$ trong báo cáo ca của chúng tôi đều không phát hiện được bất kỳ yếu tố nguy cơ liên quan nào, kể cả tiền sử gia đình về bệnh ĐMC. Cả 3 trường hợp PBTĐMCN ở đây xảy ra chỉ có thể giải thích được là do các yếu tố nguy cơ của chính thai kỳ gây ra, nhất là $2 \mathrm{BN}$ thai 31 và 33 tuần tuổi.

PBTĐMCN nhất là týp $\mathrm{A}$ khi đã xuất hiện trong thai kỳ có thể gây tử vong rất cao cho cả mẹ và con, do đó cần phải có các biện pháp điều trị can thiệp cấp cứu kịp thời. Mục tiêu điều trị là đảm bảo giữ được sự sống còn của cả mẹ và con. Hiện nay vẫn chưa có các khuyến cáo thực hành lâm sàng với chứng cứ thuyết phục cho điều trị, trong bối cảnh đó, chúng ta tiến hành điều trị dựa vào sự đồng thuận chung của các chuyên gia cũng như các kinh nghiệm có được từ các báo cáo ca lâm sàng trên thế giới. Dù các kinh nghiệm có được không nhiều, nhưng khi kết hợp với hội chẩn nhóm giữa các bác sĩ sản khoa, phẫu thuật tim và gây mê hồi sức, chúng ta có thể đưa ra được các quyết định điều trị kịp thời và có kết quả rất tốt. Nhìn chung, các chuyên gia đều thống nhất: (1) Thai kỳ $<28$ tuần, nên phẫu thuật điều trị PBTĐMCN trước, không mổ lấy thai. (2) Thai kỳ $>32$ tuần, nên phẫu thuật lấy thai trước, sau đó tiếp tục điều trị PBTÐMCN. (3) Thai kỳ giữa 28 - 32 tuần, nên phân tích giữa nguy cơ và lợi ích của việc lấy thai sớm nhằm đảm bảo lợi ích sống còn tốt nhất cho mẹ và con. Cả $3 \mathrm{BN}$ chúng tôi trình bày đều được điều trị theo như hướng khuyến cáo chung vừa nêu. Thai phụ với thai 33 tuần được tiêm thuốc kích thích trưởng thành phổi thai nhi trong vòng 24 giờ trước khi mổ lấy thai nhi, đồng thời tiếp ngay sau đó phẫu thuật sửa van $\mathrm{ĐMC}$, Thay $\mathrm{ÐMC}$ ngực lên bằng Prothese valsalva số 28 , cắm lại 2 lỗ vành. Thai phụ với thai 12 tuần được điều trị phẫu thuật PBTĐMCN, song song đó, các BS sản khoa túc trực ngay trong lúc mổ để hổ trợ phòng trường hợp sảy thai gây băng huyết đe dọa sản phụ. Điều này rất dễ xảy ra bởi vì phẫu thuật điều trị PBTĐMCN đòi hỏi phải hạ thấp thân nhiệt và huyết áp của sản phụ trong lúc mổ trong khi đây lại chính là những yếu tố làm gia tăng rất cao khả năng sảy thai. Sau phẫu thuật điều trị PBTĐMCN thành công, thai phụ cần được điều trị bằng progesterone để phòng ngừa nguy cơ sảy thai vẫn còn. Riêng thai phụ với thai 31 tuần, sau khi hội chẩn kỹ lưỡng và kịp thời giữa các $\mathrm{BS}$ sản khoa, phẫu thuật viên và gây mê hồi sức, $\mathrm{BN}$ được tiêm thuốc kích thích trưởng thành phổi thai nhi mỗi 12 giờ, trong vòng 24 giờ sau đó tiến hành mổ lấy thai trước khi phẫu thuật điều trị PBTĐMCN.

Kiểm soát tốt huyết áp (huyết áp tâm thu < $130 \mathrm{mmHg}$ ) và nhịp tim là một trong những điểm then chốt khi hồi sức cho thai phụ bị PBTĐMCN. Chọn lựa thuốc truyền tĩnh mạch hay uống phụ thuốc vào tốc độ tăng huyết áp và mức độ huyết áp. Methyldopa đã từng được sử dụng rộng rãi trong điều trị THA thai kỳ và an toàn cho thai nhi, tuy nhiên thuốc làm hạ huyết áp nhẹ và thời gian khởi phát tác dụng chậm (3 - 6 giờ). Thuốc 
chẹn thụ thể Beta là lựa chọn hàng đầu vì làm giảm lực căng xé thành mạch chủ và làm giảm tốc độ dãn ĐMC, trong đó Labetalol, Metoprolol và Pindolol là các thuốc khuyến cáo sử dụng an toàn, riêng Atenolol có thể làm chậm sự phá triển thai nhi nên không được khuyến cáo. Trong số các thuốc thuộc nhóm chẹn kênh canxi đường uống, Nifedipine tác dụng kéo dài được khuyến cáo. Ngoài ra, nhóm thuốc này còn có dạng truyền tĩnh mạch là Nicardipine giúp kiểm soát nhanh, an toàn và hiệu quả mức huyết áp $\mathrm{BN}$. Chống chỉ định sử dụng các thuốc nhóm ức chế men chuyển, chẹn thụ thể Angiotensin II, ức chế Renin trực tiếp cho thai phụ vì có thể gây dị dạng hệ thần kinh trung ương, tim mạch thai nhi nếu thai phụ uống thuốc trong tam cá nguyệt đầu và gây bất thường thận thai nhi nếu dùng thuốc trong nữa sau của thai kỳ. Thuốc kháng thụ thể Mineralocorticoid (spironolactone) qua nhau thai và chưa từng được chứng minh tính an toàn khi sử dụng trong thai kỳ. Nitroprusside có ở dạng truyền tĩnh mạch, nhưng do thuốc có thể gây ngộ độ cyanide cho thai nhi nên chỉ được xếp vào chọn lựa cuối cùng và chỉ sử dụng điều trị cấp cứu trong thời gian ngắn (liều $0,5-10$ $\mathrm{mcg} / \mathrm{Kg} / \mathrm{phút}$ ) khi mà THA ở thai phụ trơ với các biện pháp điều trị khác. Cả 3 thai phụ trong báo cáo của chúng tôi đều ghi nhận không có tiền căn THA và trị số huyết áp tâm thu lúc nhập viện 130 - 140 mmHg được ổn định $(<130$ mmHg) khi $\mathrm{BN}$ được điều trị giảm đau.

\section{KẾT LUẬN}

PBTĐMCN týp A là bệnh lý hiếm gặp trong thai kỳ nhưng nguy cơ gây tử vong cao cho cả mẹ và thai nhi. Nguyên nhân thường gặp nhất là hội chứng Marfan. Điều trị đòi hỏi phải có sự phối hợp chặt chẽ giữa các BS sản khoa, phẫu thuật viên tim mạch và $\mathrm{BS}$ gây mê, hồi sức tim nhằm chẩn đoán và kịp thời can thiệp điều trị giúp bảo toàn sự sống còn của cả mẹ và thai nhi. Hiện vẫn chưa có một khuyến cáo điều trị nào với đủ những chứng cứ thuyết phục mạnh mẽ cho bệnh cảnh này, song quyết định điều trị thống nhất chung đều dựa vào kiểu bóc tách ĐMC của thai phụ và tuổi thai. Cần có nhiều hơn nữa những báo cáo ca cũng như các nghiên cứu với cỡ mẫu đủ lớn giúp tạo cơ sở thống kê vững chắc cho các khuyến cáo cụ thể trong tương lai.

\section{TÀI LIỆU THAM KHẢO}

[1] Ch'ng S. L. et al. (2013), "Stanford type a aortic dissection in pregnancy: a diagnostic and management challenge", Heart Lung Circ. 22 (1), pp. 12-18.

[2] Hagan P. G. et al. (2000), "The International Registry of Acute Aortic Dissection (IRAD): new insights into an old disease", Jama. 283 (7), pp. 897-903.

[3] Immer F. F. et al. (2003), "Aortic dissection in pregnancy: analysis of risk factors and outcome", Ann Thorac Surg. 76 (1), pp. 309-314.

[4] Manalo-Estrella P. et al. (1967), "Histopathologic findings in human aortic media associated with pregnancy", Arch Pathol. 83 (4), pp. 336-341.

[5] Meszaros I. et al. (2000), "Epidemiology and clinicopathology of aortic dissection", Chest. 117 (5), pp. 1271-1278.

[6] Pitt M. P. et al. (1997), "The natural history of thoracic aortic aneurysm disease: an overview", J Card Surg. 12 (2 Suppl), pp. 270-278.

[7] Thalmann M. et al. (2011), "Acute type A aortic dissection and pregnancy: a population-based study", Eur J Cardiothorac Surg. 39 (6), pp. e159-163.

[8] Shihata M. et al. (2008), Repair of an acute type A aortic dissection combined with an emergency cesarean section in a pregnant woman, Vol. 7. 